Article

\title{
Brassinosteroids Regulate Antioxidant System and Protect Chloroplast Ultrastructure of Autotoxicity-Stressed Cucumber (Cucumis sativus L.) Seedlings
}

\author{
Ping Yang ${ }^{1}$, Muhammad Azher Nawaz ${ }^{2}$, Fuxin $\mathrm{Li}^{1}{ }^{1}$, Lisha Bai ${ }^{1}$ and Jie Li ${ }^{1}, * \mathbb{C}$ \\ 1 College of Life Science and Technology, Honghe University, Mengzi 661100, China; gsau123@163.com (P.Y.); \\ 3130729450@qq.com (F.L.); 310334970@qq.com (L.B.) \\ 2 Department of Horticulture, College of Agriculture, University of Sargodha, Sargodha Punjab 40100, \\ Pakistan; azher.nawaz@uos.edu.pk \\ * Correspondence: gsau23@126.com; Tel.: +86-0873-3698-575; Fax: +86-0873-3698-575
}

Received: 21 March 2019; Accepted: 21 May 2019; Published: 26 May 2019

check for updates

\begin{abstract}
Autotoxicity is a common problem being faced in protected vegetable cultivation system. Phytoremediation of plant autotoxicity is an emerging concept to minimize deterioration of soil environment and reduction of yield and quality of vegetable crops. Brassinosteroids (BRs) have been reported as a potential phytohormone to assist phytoremediation. However, the effects of BRs-induced autotoxicity stress on plant growth, photosynthesis and antioxidant defense system are poorly understood. Hence, we focused on the changes in physiological characteristics and ultrastructure of cucumber leaves in response to the application of 24-epibrassinolide (EBR) under autotoxicity stress conditions. The results showed that leaf area, plant height, fresh weight and dry weight of cucumber were obviously decreased under autotoxicity stress conditions. EBR application obviously improved the phenotypic characteristics of cucumber seedlings. Chlorophyll content, net photosynthetic rate, stomatal conductance and transpiration rate of cucumber leaves were markedly reduced under autotoxicity stress conditions. Application of EBR improved the photosynthetic pigments (chlorophyll a by $15.80 \%$, chlorophyll b by $18.70 \%$ and total chlorophyll content by $17.30 \%$ ), net photosynthetic rate by $36.40 \%$ and stomatal opening of leaves under autotoxicity stress conditions. EBR application also maintained the integrity of chloroplast and thylakoid structures under autotoxicity stress conditions. The activity of catalase (CAT), peroxidase (POD) and ascorbate peroxidase (APX) and antioxidative compounds ascorbate (AsA) and reduced glutathione (GSH) contents were markedly decreased, however, these were obviously increased after EBR application under autotoxicity stress. EBR application also increased the soluble sugar and protein, and proline concentration by $59.70 \%$, $7.22 \%$ and $36.58 \%$, respectively in the leaves of cucumber, decreased malondialdehyde by $24.13 \%$ and reactive oxygen species contents $\left(\mathrm{H}_{2} \mathrm{O}_{2}\right.$ by $35.17 \%, \mathrm{O}_{2}{ }^{-}$by $12.01 \%$ and ${ }^{\circ} \mathrm{OH}$ by $\left.16.59 \%\right)$, and reduced the relative permeability of the cell membrane by $14.31 \%$. These findings suggest that EBR application enhanced the photosynthetic capacity of leaves, maintained the integrity of chloroplast and thylakoid structures, and effectively alleviated the damage of membrane caused by lipid peroxidation and root damage under autotoxicity stress conditions. The growth inhibition effect of autotoxicity stress on cucumber was reduced by EBR application.
\end{abstract}

Keywords: Cucumis sativus L.; brassinolides; photosynthesis; ultrastructure; reactive oxygen species; autotoxicity 


\section{Introduction}

The rapid developments in protected cultivation and intensive cropping pattern have led to an increased index of multiple cropping [1,2]. The continuous cropping results in the deterioration of soil environment, serious diseases and pests attack on vegetables, and reduction of yield and quality of vegetable crops $[3,4]$. Continuous cropping has become the main factor limiting vegetable's production [5]. If the same type of vegetable is cultivated continuously, it affects the species and quantity of soil microbes. The root system of the vegetable secrete the same substances (roots exudates) for a long time that may affect microbial diversity and microbial population and increase the incidence of soil-borne diseases [6]. Autotoxicity is a common problem being faced in protected vegetable cultivation system because after harvesting the roots remains in the soil [7]. A range of secondary metabolites in the residual root of vegetables, such as cinnamic acid (CA), flavones and terpenoids are the potential autotoxins $[8,9]$.

Cucumber (Cucumis sativus L.) is one of the main vegetable cultivated at a commercial scale across the World. Likewise, cucumber is widely cultivated in solar greenhouses and plastic greenhouses in northern China [10]. Principally, farmers annually grow the same crop for years to maximize economic return $[4,11,12]$. Continuous cultivation of cucumber on the same piece of land is a major hindrance for the further development of cucumber industry [12]. Grafting is an important technique in a modern vegetable production system because it provides resistance against soil-borne diseases leading towards increased yield [13-15]. At present, grafting is widely used to alleviate the obstacles caused by continuous cropping of cucumber, but the production of grafted transplants takes time, resources, and it is labor intensive [16,17]. Additionally, the use of rootstock during the process of grafting has certain negative impacts on fruit shape, flavor, and quality of cucumber [18]. Thus, there is a need to find a simple and labor-saving method that protects cucumber plants from stress without altering the flavor and quality of the cucumber.

Brassinosteroids (BRs) widely exist in plant species and are involved in the regulation of plant growth and development [19]. Brassinosteroids are involved in plant metabolism; promote cell division and cell elongation, and key physiological processes, such as photosynthesis and antioxidant system leading towards improved plant growth and development [20-23]. BRs maintain a high level of chlorophyll content and improve the photosynthetic performance of plants [24]. BRs enhance the activity of protective enzymes in plants and help reduce oxidative damage caused by reactive oxygen species (ROS) thereby improving resistance against disease and other kinds of environmental stresses $[25,26]$. Additionally, BRs promote water absorption capacity of plants under drought stress, maintain the stability of the cell membrane, regulate physiological and biochemical process within cells, and improve the yield and quality of crops [27]. According to a report, the application of BRs alleviates hypoxia stress on mitochondria and ultrastructure of melon roots [28].

Liu et al. [29] found that 24-epibrassinolide (EBR) promotes the growth of bamboo by improving the activity of antioxidants, enhancing the antioxidant capacity of plants, and increasing the proline and soluble protein contents. BRs also alleviate membrane damage caused by lipid peroxidation under low temperature stress conditions.

The alternate techniques to improve stress tolerance of plants, such as the use of BRs are getting attention plant biologist [21]. BRs play an important role in hormonal homeostasis particularly under stress conditions [20]. Cinnamic acid (CA) is a major autotoxin secreted from the roots in cucumber plant. CA has an inhibitory effect on the regulation of plant morphogenesis and development [30]. The information regarding the physiological changes in cucumber under autotoxicity stress conditions, particularly in the antioxidant system and photosynthetic characteristics is limited. Here, we hypothesized that EBR alleviates the CA-induced stress by improving photosynthesis and strengthening antioxidant systems. The findings reported in this study may provide a theoretical basis for BRs as a potential phytohormone that can be utilized to alleviate autotoxicity stress of cucumber. 


\section{Materials and Methods}

EBR was purchased from Sigma-Aldrich (St.Louis, MO, USA), and dissolved in a small quantity of ethanol and then the final volume was made by adding distilled water. The seeds of cucumber cultivar Changlu No. 1 were soaked in water at $28-30{ }^{\circ} \mathrm{C}$ for $6 \mathrm{~h}$ and then placed in an incubator for germination. After germination, the seeds were planted in seeding trays and the trays were placed in a growth chamber. The temperature of growth chamber was set at $28 \pm 1{ }^{\circ} \mathrm{C}$ for day and the night temperature was maintained at $18 \pm 1^{\circ} \mathrm{C}$ having a $12 \mathrm{~h}$ photoperiod $\left(500 \mu \mathrm{mol} \mathrm{m} \mathrm{m}^{-2} \mathrm{~s}^{-1}\right)$ and relative humidity was adjusted to $70-80 \%$. After the second leaf emerged, uniform seedlings were transferred to a container filled with half-strength Hoagland solution. The plants were kept in the growth chamber for seven days. Plants were exposed to four treatments: $1 / 2$ Hoagland's nutrient solution as the control group (C); application of $0.1 \mu \mathrm{M}$ EBR in $1 / 2$ Hoagland's nutrient solution (C + EBR); application of $100 \mathrm{mM}$ cinnamic acid in 1/2 Hoagland's nutrient solution (CA); application of $100 \mathrm{mM}$ cinnamic acid and $0.1 \mu \mathrm{M}$ EBR in 1/2 Hoagland's nutrient solution (CA + EBR). In this study, 27 plants were used for every treatment. The concentration of $\mathrm{CA}$ and EBR were determined according to the procedure described in our previous studies [31]. The nutrient solution was replaced every three days to avoid deficiency of any specific ion.

\subsection{Determination of Morphological Characteristics}

Three cucumber seedlings were selected from each treatment; ruler and vernier caliper were used to measure the plant height and stem diameter, respectively. The leaf area was assessed by using leaf area meter. Second true leaf from the top was selected to measure leaf area. The data for all these parameters were measured after seven days of treatment.

\subsection{Measurement of Biomass}

Three uniform cucumber seedlings were harvested from all treatments. Plants were washed with clear water and surface dried by an absorbent paper, the fresh weight of shoot (above ground part of the plant) and root (underground part of the plant) was measured by an electric balance. The samples were placed in paper bags, labeled and dried in an oven initially at $105^{\circ} \mathrm{C}$ for $15 \mathrm{~min}$ and then at $80^{\circ} \mathrm{C}$, until the samples maintained a constant dry weight. The dry weight of shoot and root was measured by electronic balance. The data were measured after seven days of treatment.

\subsection{Determination of Root Morphology and Root Activity}

The root length from root tip to rhizome junction was measured with a ruler and the root morphology analysis was performed using root scanner (Epson Expression 1180XL, Seiko Epson Corp., Nagano-ken, Japan) and WinRHIZO root analysis system (Regent Instruments, Quebec, Canada). The root activity of cucumber seedlings was determined by TTC chloride method with $0.5 \mathrm{~g}$ fresh sample after 7 days of treatment.

\subsection{Determination of Photosynthetic Pigments and Observation of Stomatal Opening}

The acetone ( $80 \%)$ extraction method was used to determine the photosynthetic pigments [32]. The stomatal opening of leaves was observed using a light microscope at 40× magnification.

\subsection{Determination of Gas Exchange Parameters}

The net photosynthetic rate (Pn), stomatal conductance (Gs), transpiration rate (Tr) and intercellular $\mathrm{CO}_{2}$ concentration ( $\mathrm{Ci}$ ) of the cucumber leaves were determined by using a portable photosynthesis analysis system (Li-6400, Li-COR Company, Lincoln, NE, USA) on a sunny day at 09:00 to 11:00. The temperature of the leaf chamber was controlled at $25 \pm 1^{\circ} \mathrm{C}$, PPFD was $600 \mu \mathrm{mol} \mathrm{m}^{-2} \mathrm{~s}^{-1}$, and the $\mathrm{CO}_{2}$ concentration was adjusted to $360 \pm 10 \mu \mathrm{mol} \mathrm{mol}{ }^{-1}$. 


\subsection{Ultrastructure of Chloroplast and Thylakoid}

The ultrastructure of chloroplast and thylakoid of cucumber leaves were observed using transmission electron microscope (TEM-100CX, JEOL Company, Tokyo, Japan) at an accelerating voltage of $75 \mathrm{kV}$ as explained by Zeng et al. [33]. The cucumber leaf was cut into $1 \mathrm{~mm} \times 5 \mathrm{~mm}$ pieces in the midsection on both sides of the mid rib of the leaf, and the cut rectangular pieces were immersed into the $4 \%$ glutaraldehyde at $4{ }^{\circ} \mathrm{C}$ and fixed for $12 \mathrm{~h}$. After washing with phosphoric acid buffer, the samples were fixed with $1 \%$ osmic acid at $4{ }^{\circ} \mathrm{C}$ for $6 \mathrm{~h}$. Then, the samples were dehydrated by ethanol with different concentration gradients and then immersed and embedded in epoxy resin. The samples were cut into $1 \mu \mathrm{m}$ slices by an ultrathin microtome. The sections were stained with uranyl acetate and lead citrate and then observed and photographed using a transmission electron microscope.

\subsection{ROS and Lipid Peroxidation Detection and Quantification}

The stained images of $\mathrm{H}_{2} \mathrm{O}_{2}$ and $\mathrm{O}_{2}{ }^{-}$were taken according to the procedure described by Ma et al. [34]. For $\mathrm{H}_{2} \mathrm{O}_{2}$, the cucumber leaves were infiltrated with $0.1 \mathrm{mg} \mathrm{mL}^{-1}$ DAB working solution in $50 \mathrm{mM}$ Tris-acetate ( $\mathrm{pH} 3.8$ ) under dark conditions and incubated for $24 \mathrm{~h}$ at $25^{\circ} \mathrm{C}$. Then the leaves were faded with the $80 \%$ ethanol for $15 \mathrm{~min}$ at $90^{\circ} \mathrm{C}$. Finally, the cucumber leaves were mounted with a mixture of ethanol/acetic acid/glycerol $(3: 1: 1, v / v)$ at $4{ }^{\circ} \mathrm{C}$ and photographed. $\mathrm{For}_{2}{ }^{-}$, the cucumber leaves were infiltrated with $0.1 \mathrm{mg} \mathrm{mL}^{-1}$ NBT working solution in $25 \mathrm{mM} \mathrm{K-HEPES} \mathrm{buffer} \mathrm{(pH} \mathrm{7.8)}$ under dark conditions and incubated for $2 \mathrm{~h}$ at $25^{\circ} \mathrm{C}$. The steps for fading and mounting were the same as described for $\mathrm{H}_{2} \mathrm{O}_{2}$. Schiff's reagent was utilized for histochemical detection and quantification of aldehydes produced from the lipid peroxide that was the malondialdehyde (MDA). Their contents were quantified using spectrophotometer by a peroxidase-coupled assay. The chopped leaves in ice bath were ground with $0.1 \%$ trichloroacetic acid (TCA). The homogenates were centrifuged at $12,000 \times \mathrm{g}$ for $15 \mathrm{~min}$ at $4{ }^{\circ} \mathrm{C}$. The centrifugal supernatant with $0.1 \mathrm{M}$ phosphate buffer solution (PBS) ( $\mathrm{pH}$ 7.0) was placed in darkness for $1 \mathrm{~h}$ and then determined by spectrophotometer at $390 \mathrm{~nm}$ to calculate the concentration of $\mathrm{H}_{2} \mathrm{O}_{2}$ in the leaves. The $\mathrm{O}_{2}{ }^{-}$production rate (nitrite formation from hydroxylamine) was monitored in the presence of $\mathrm{O}_{2}{ }^{-}$and calculated as a standard curve with $\mathrm{NO}_{2}{ }^{-}$. For the quantification of ${ }^{\bullet} \mathrm{OH}$, the samples were homogenized in $50 \mathrm{mM}$ PBS buffer (pH 7.0) and centrifuged at $10,000 \times \mathrm{g}$ for $10 \mathrm{~min}$ at $4{ }^{\circ} \mathrm{C}$. The supernatant with $2.5 \mathrm{mM}$ 2-deoxyribose was developed at $35^{\circ} \mathrm{C}$ in the dark for $1 \mathrm{~h}$. The mixture with $1 \%(w / v)$ thiobarbituric acid (TBA) and acetic acid was boiled for $30 \mathrm{~min}$ and immediately cooled for $10 \mathrm{~min}$ on ice, and then absorbance was measured at $532 \mathrm{~nm}$. MDA content was measured as an end product of lipid peroxidation via 2-thiobarbituric acid (TBA) reaction. The absorbance of the red adduct was recorded at 450, 532, and $600 \mathrm{~nm}$ to calculate the concentration of MDA in the leaves.

\subsection{Activity of Antioxidant Enzymes and Contents of Proline, Soluble Sugar, and Protein}

The antioxidant enzyme activities of superoxide dismutase (SOD), peroxidase (POD), catalase (CAT), and ascorbate peroxidase (APX) were measured using the procedure described by Li et al. [35]. To measure the antioxidant activities and contents, frozen leaf samples $(0.5 \mathrm{~g})$ were ground and homogenized using $5 \mathrm{~mL}$ ice-cold $25 \mathrm{mM}$ HEPES buffer with a $\mathrm{pH}$ of 7.8 containing $0.2 \mathrm{mM}$ ethylene diamine tetraacetic acid (EDTA), $2 \mathrm{mM}$ AsA, and $2 \%$ polyvinylpolypyrrolidone at $4{ }^{\circ} \mathrm{C}$. This homogenate was centrifuged at $4{ }^{\circ} \mathrm{C}$ at $12,000 \times g$ and supernatant was utilized for enzymes analysis and quantification. The SOD activity was measured by assessing its ability to inhibit the photochemical reduction of nitroblue tetrazolium (NBT). One unit of SOD was considered when it inhibited the photochemical reduction of NBT by $50 \%$. For the measurement of POD activity, guaiacol method was followed, and one unit of POD activity was 0.01 increases per minute at $470 \mathrm{~nm}$. The CAT activity was measured by adding $\mathrm{H}_{2} \mathrm{O}_{2}$, and immediately measuring the decrease rate of $\mathrm{H}_{2} \mathrm{O}_{2}$ at $240 \mathrm{~nm}$. One unit of CAT activity was the amount of enzyme required to decompose $1 \mu \mathrm{mol}$ 
$\mathrm{H}_{2} \mathrm{O}_{2}$ in $1 \mathrm{~min}$. APX was measured by calculating the rate of decrease in absorbance at $290 \mathrm{~nm}$, and one unit of APX activity was the reduction in AsA in 1 min.

AsA and GSH contents were measured from the leaf samples. Samples were ground and homogenized in a cold mortar placed on ice using 5\% ice-cold meta-phosphoric acid. AsA was measured by grinding leaf samples in liquid nitrogen, and 1 gram of grounded powder was mixed with $600 \mu \mathrm{L}$ of $6 \%$ trichloroacetic acid. Samples were then centrifuged at $12,000 \times g$ for $15 \min$ at $4{ }^{\circ} \mathrm{C}$. AsA was calculated using standard curve prepared according to the method described by Stevens et al. [36]. The GSH content was measured on the basis of reduction of 2-nitrobenzoic acid (DTNB) according to the method of Griffith [37].

After seven days of treatment, proline, soluble sugar and protein contents of the leaves were measured. Briefly, proline content was measured using 3\% 5-sulphosalicylic acid as an extraction solution at room temperature according to the method of Bates et al. [38]. Soluble sugars were determined using anthrone colorimetry and estimated on fresh weight basis according to the method of Buysse and Merckx [39]. The soluble protein was measured on a fresh weight basis using the method described by Bradford [40].

\subsection{Statistical Analysis}

The data were subjected to ANOVA using SPSS statistical package (13.0, SPSS Institute Ltd, New York, NY, USA). The treatment means were compared by using Duncan's multiple range test $(p<0.05)$. The data were expressed as means of three replicates ( \pm standard error (SE) 3 ).

\section{Results}

\subsection{Morphological Changes}

No difference for morphological characteristics, such as plant height, stem diameter and leaf area of cucumber seedlings was observed with or without the exogenous EBR application under normal growth conditions. Application of EBR improved plant height and leaf area by $31.7 \%$ and $44.4 \%$, respectively compared with CA treatment under autotoxicity stress conditions (Figure 1 and Table 1). The fresh weight and dry weight of shoot were improved by $32.90 \%$ and $30.10 \%$, respectively in EBR treated plants compared with CA treatment. Fresh weight and dry weight of the root (underground part) of EBR-treated cucumber plants were higher compared with CA treatment; however, the differences were non-significant (Table 2). Under normal growth conditions, there was no significant difference in fresh and dry weight of aboveground and underground parts between the EBR-treated and non-EBR treated cucumber seedlings.

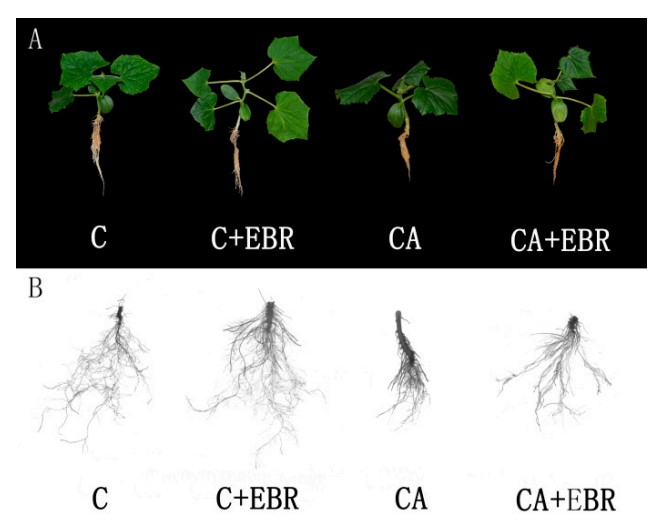

Figure 1. Phenotypic changes (A) in autotoxicity-stressed cucumber seedlings with or without the application of 24-epibrassinolide (EBR); the root phenotype (B) after $7 \mathrm{~d}$ of stress treatment. C, $1 / 2$ Hoagland's nutrient solution; C + EBR, application of $0.1 \mu \mathrm{M}$ EBR in 1/2 Hoagland's nutrient solution; CA, application of $100 \mathrm{mM}$ cinnamic acid in 1/2 Hoagland's nutrient solution; CA + EBR, application of $100 \mathrm{mM}$ cinnamic acid and $0.1 \mu \mathrm{M}$ EBR in $1 / 2$ Hoagland's nutrient solution. 
Table 1. Morphological changes of cucumber seedlings after treatment with EBR under autotoxicity stress conditions.

\begin{tabular}{cccc}
\hline Treatment & Plant Height $\mathbf{( c m )}$ & Stem Diameter $(\mathbf{c m})$ & Leaf Area $\left.\mathbf{( m m}^{2}\right)$ \\
\hline C & $16.07 \pm 0.53 \mathrm{a}$ & $0.65 \pm 0.14 \mathrm{a}$ & $2434.31 \pm 25.94 \mathrm{a}$ \\
$\mathrm{C}+\mathrm{EBR}$ & $16.97 \pm 0.23 \mathrm{a}$ & $0.59 \pm 0.01 \mathrm{a}$ & $2545.29 \pm 67.98 \mathrm{a}$ \\
CA & $9.65 \pm 0.61 \mathrm{c}$ & $0.40 \pm 0.02 \mathrm{~b}$ & $879.72 \pm 35.41 \mathrm{c}$ \\
CA + EBR & $14.13 \pm 0.94 \mathrm{~b}$ & $0.49 \pm 0.03 \mathrm{ab}$ & $1583.58 \pm 29.81 \mathrm{~b}$ \\
\hline
\end{tabular}

Different lowercase letters in the same column indicate a significant difference between the treatments at $p<0.05$. Data are the mean \pm standard error of the mean of at least three different replicates of each treatment. C, $1 / 2$ Hoagland's nutrient solution; C + EBR, application of $0.1 \mu \mathrm{M}$ EBR in $1 / 2$ Hoagland's nutrient solution; CA, application of $100 \mathrm{mM}$ cinnamic acid in 1/2 Hoagland's nutrient solution; CA + EBR, application of $100 \mathrm{mM}$ cinnamic acid and $0.1 \mu \mathrm{M}$ EBR in $1 / 2$ Hoagland's nutrient solution.

Table 2. Effects of exogenous EBR on the biomass of cucumber seedlings under autotoxicity stress conditions.

\begin{tabular}{ccccc}
\hline \multirow{2}{*}{ Treatment } & \multicolumn{2}{c}{ Fresh Weight (g) } & \multicolumn{2}{c}{ Dry Weight (g) } \\
\cline { 2 - 5 } & Above-Ground & Underground & Above-Ground & Underground \\
\hline C & $6.67 \pm 0.69 \mathrm{a}$ & $0.74 \pm 0.12 \mathrm{a}$ & $0.49 \pm 0.03 \mathrm{a}$ & $0.054 \pm 0.008 \mathrm{a}$ \\
EBR & $7.14 \pm 0.70 \mathrm{a}$ & $0.83 \pm 0.31 \mathrm{a}$ & $0.48 \pm 0.06 \mathrm{a}$ & $0.065 \pm 0.012 \mathrm{ab}$ \\
CA & $3.74 \pm 0.24 \mathrm{c}$ & $0.63 \pm 0.04 \mathrm{a}$ & $0.28 \pm 0.03 \mathrm{c}$ & $0.041 \pm 0.007 \mathrm{ab}$ \\
CA+EBR & $5.57 \pm 0.37 \mathrm{~b}$ & $0.73 \pm 0.06 \mathrm{a}$ & $0.40 \pm 0.01 \mathrm{~b}$ & $0.052 \pm 0.003 \mathrm{~b}$ \\
\hline
\end{tabular}

Different lowercase letters in the same column indicate a significant difference between the treatments at $p<0.05$. Data are the mean \pm standard error of the mean of at least three different replicates of each treatment. C, 1/2 Hoagland's nutrient solution; C + EBR, application of $0.1 \mu \mathrm{M}$ EBR in 1/2 Hoagland's nutrient solution; CA, application of $100 \mathrm{mM}$ cinnamic acid in 1/2 Hoagland's nutrient solution; CA + EBR, application of $100 \mathrm{mM}$ cinnamic acid and $0.1 \mu \mathrm{M}$ EBR in $1 / 2$ Hoagland's nutrient solution.

\subsection{Root Morphology and Root Activity}

Under normal growth conditions, no significant differences for root morphology (total root length, root surface area, root volume, and root tips) were observed between EBR-treated and non- EBR treated cucumber seedlings. The total root length and root surface area under CA + EBR treatment were increased by $41.50 \%$ and $34.20 \%$, respectively, and the root volume and root tips were decreased compared with CA treatment (Figure 1, Table 3). Under normal growth conditions, the root activity of cucumber seedlings treated with EBR was not affected compared with control. The root activity in CA-treated plants was decreased by $45.80 \%$ compared with control. However, the application of EBR obviously increased the root activity $(35.40 \%)$ compared with CA-treated cucumber plants under autotoxicity stress (Figure 2).

Table 3. Effect of EBR on root morphology of cucumber seedlings under autotoxicity stress conditions.

\begin{tabular}{|c|c|c|c|c|}
\hline Treatment & $\begin{array}{l}\text { Total Root Length } \\
(\mathrm{mm})\end{array}$ & $\begin{array}{l}\text { Root Surface } \\
\qquad\left(\mathrm{cm}^{2}\right)\end{array}$ & $\begin{array}{l}\text { Root Volume } \\
\qquad\left(\mathrm{cm}^{3}\right)\end{array}$ & Root Tip Number \\
\hline C & $1642.6 \pm 162.0 \mathrm{a}$ & $354.9 \pm 27.3 \mathrm{a}$ & $1.42 \pm 0.14 \mathrm{a}$ & $161 \pm 12 \mathrm{a}$ \\
\hline $\mathrm{C}+\mathrm{EBR}$ & $1770.3 \pm 198.8 \mathrm{a}$ & $331.1 \pm 27.3 \mathrm{a}$ & $1.25 \pm 0.33 \mathrm{a}$ & $150 \pm 22 \mathrm{a}$ \\
\hline CA & $588.2 \pm 41.1 \mathrm{c}$ & $169.0 \pm 29.2 \mathrm{c}$ & $0.69 \pm 0.07 b$ & $100 \pm 7 b$ \\
\hline $\mathrm{CA}+\mathrm{EBR}$ & $1005.0 \pm 8.5 b$ & $257.0 \pm 40.5 b$ & $0.32 \pm 0.08 c$ & $69 \pm 8 c$ \\
\hline
\end{tabular}

Different lowercase letters in the same column indicate a significant difference between the treatments at $p<0.05$. Data are the mean \pm standard error of the mean of at least three different replicates of each treatment. C, 1/2 Hoagland's nutrient solution; C + EBR, application of $0.1 \mu \mathrm{M}$ EBR in 1/2 Hoagland's nutrient solution; CA, application of $100 \mathrm{mM}$ cinnamic acid in 1/2 Hoagland's nutrient solution; CA+EBR, application of $100 \mathrm{mM}$ cinnamic acid and $0.1 \mu \mathrm{M}$ EBR in $1 / 2$ Hoagland's nutrient solution. 


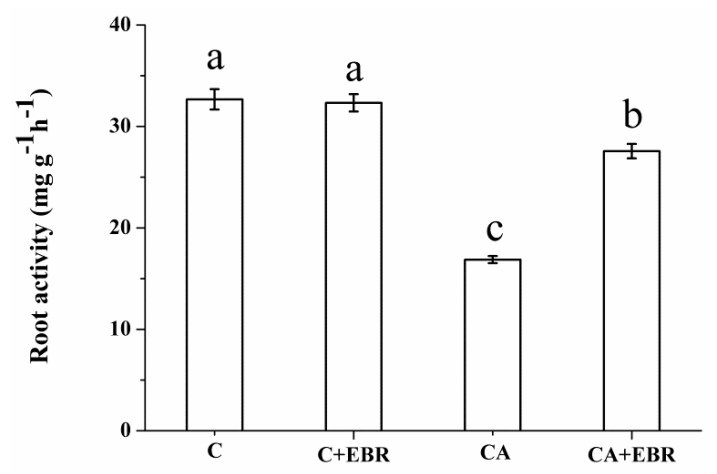

Figure 2. Root activity of cucumber seedlings exposed to autotoxicity conditions with or without the application of EBR. Values are means $\pm \mathrm{SE}(n=6)$. Letters in the column diagram indicate significant differences at $p<0.05$. C, $1 / 2$ Hoagland's nutrient solution; $C+E B R$, application of $0.1 \mu \mathrm{M}$ EBR in 1/2 Hoagland's nutrient solution; CA, application of $100 \mathrm{mM}$ cinnamic acid in $1 / 2$ Hoagland's nutrient solution; CA + EBR, application of $100 \mathrm{mM}$ cinnamic acid and $0.1 \mu \mathrm{M}$ EBR in 1/2 Hoagland's nutrient solution.

\subsection{Photosynthetic Pigments and Stomatal Opening}

EBR application improved the chlorophyll a (15.80\%), chlorophyll b $(18.70 \%)$ and total chlorophyll contents $(17.30 \%)$ compared with non-EBR treated cucumber plants under autotoxicity stress conditions (Table 4). Under normal growth conditions, there was no significant difference regarding stomatal opening between the control and EBR-treated cucumber plants. The stomatal opening of cucumber leaves was obviously increased by the application of EBR compared with CA-treated plants under autotoxicity stress (Figure 3).

Table 4. Effect of EBR on photosynthetic pigments of cucumber seedlings under autotoxicity stress conditions (mg/g FW).

\begin{tabular}{ccccc}
\hline Treatment & Chl a Content & Chl b Content & Total Chl Content & Carotenoid Content \\
\hline C & $27.19 \pm 0.07 \mathrm{a}$ & $31.70 \pm 1.03 \mathrm{a}$ & $58.89 \pm 1.07 \mathrm{a}$ & $9.93 \pm 1.03 \mathrm{a}$ \\
C + EBR & $27.30 \pm 0.58 \mathrm{a}$ & $31.80 \pm 2.18 \mathrm{a}$ & $59.10 \pm 1.83 \mathrm{a}$ & $10.41 \pm 1.45 \mathrm{a}$ \\
CA & $21.14 \pm 0.05 \mathrm{c}$ & $22.83 \pm 1.74 \mathrm{c}$ & $43.97 \pm 1.69 \mathrm{c}$ & $6.64 \pm 0.47 \mathrm{~b}$ \\
CA + EBR & $25.11 \pm 1.77 \mathrm{~b}$ & $28.09 \pm 0.61 \mathrm{~b}$ & $53.19 \pm 1.54 \mathrm{~b}$ & $8.64 \pm 0.32 \mathrm{ab}$ \\
\hline
\end{tabular}

Different lowercase letters in the same column indicate a significant difference between the treatments at $p<0.05$. Data are the mean \pm standard error of the mean of at least three different replicates of each treatment. C, $1 / 2$ Hoagland's nutrient solution; C + EBR, application of $0.1 \mu \mathrm{M}$ EBR in $1 / 2$ Hoagland's nutrient solution; CA, application of $100 \mathrm{mM}$ cinnamic acid in $1 / 2$ Hoagland's nutrient solution; CA + EBR, application of $100 \mathrm{mM}$ cinnamic acid and $0.1 \mu \mathrm{M}$ EBR in $1 / 2$ Hoagland's nutrient solution.
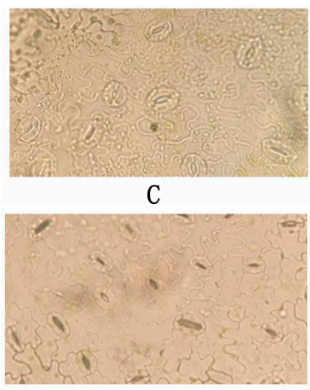

CA

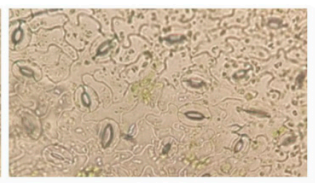

$\mathrm{C}+\mathrm{EBR}$

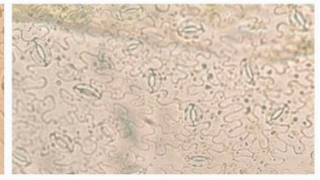

$\mathrm{CA}+\mathrm{EBR}$

Figure 3. Stomatal opening of cucumber leaves exposed to autotoxicity conditions with or without the application of EBR. C, 1/2 Hoagland's nutrient solution; C + EBR, application of $0.1 \mu \mathrm{M}$ EBR in 1/2 Hoagland's nutrient solution; CA, application of $100 \mathrm{mM}$ cinnamic acid in $1 / 2$ Hoagland's nutrient solution; CA + EBR, application of $100 \mathrm{mM}$ cinnamic acid and $0.1 \mu \mathrm{M}$ EBR in 1/2 Hoagland's nutrient solution. 


\subsection{Gas Exchange}

Under normal growth conditions, no difference was observed for photosynthetic parameters (Pn, Ci, Gs, and Tr) between the control and EBR-treated cucumber plants. However, exogenous EBR application obviously increased the Pn by $36.40 \%$ compared with CA-treated cucumber plants under autotoxicity stress. Ci, Gs and Tr were not affected by the application of EBR under autotoxicity stress conditions (Table 5).

Table 5. Effect of EBR on the Pn, Ci, Gs and Tr of cucumber leaf under autotoxicity stress conditions.

\begin{tabular}{|c|c|c|c|c|}
\hline Treatment & $\operatorname{Pn}\left(\mu \mathrm{mol}\left(\mathrm{CO}_{2}\right) \mathrm{m}^{-2} \mathrm{~s}^{-1}\right)$ & $\mathrm{Ci}(\mu \mathrm{mol} \mathrm{mol}-1)$ & $\mathrm{Gs}\left(\mathrm{mmol}\left(\mathrm{H}_{2} \mathrm{O}\right) \mathrm{m}^{2} \mathrm{~s}^{-}\right)$ & 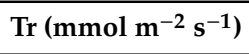 \\
\hline $\mathrm{C}$ & $12.7 \pm 1.0 \mathrm{a}$ & $341.3 \pm 4.7 \mathrm{a}$ & $32.2 \pm 3.9 \mathrm{a}$ & $443.3 \pm 31.0 \mathrm{a}$ \\
\hline$C+E B R$ & $11.3 \pm 1.1 \mathrm{a}$ & $306.7 \pm 43.4 \mathrm{a}$ & $23.9 \pm 16.3 \mathrm{a}$ & $319.3 \pm 146.0 \mathrm{a}$ \\
\hline CA & $4.2 \pm 0.3 c$ & $202.3 \pm 51.3 b$ & $3.5 \pm 0.7 \mathrm{~b}$ & $71.0 \pm 4.2 \mathrm{~b}$ \\
\hline $\mathrm{CA}+\mathrm{EBR}$ & $6.6 \pm 1.4 b$ & $167.0 \pm 36.3 b$ & $4.5 \pm 1.4 \mathrm{~b}$ & $115.3 \pm 20.3 b$ \\
\hline
\end{tabular}

Different lowercase letters in the same column indicate a significant difference between the treatments at $p<0.05$. Data are the mean \pm standard error of the mean of at least three different replicates of each treatment. Pn, net photosynthetic rate; $\mathrm{Gs}$, stomatal conductance; $\mathrm{Tr}$, transpiration rate; $\mathrm{Ci}$, intercellular $\mathrm{CO}_{2}$ concentration. $\mathrm{C}$, $1 / 2$ Hoagland's nutrient solution; C + EBR, application of $0.1 \mu \mathrm{M}$ EBR in $1 / 2$ Hoagland's nutrient solution; CA, application of $100 \mathrm{mM}$ cinnamic acid in 1/2 Hoagland's nutrient solution; CA + EBR, application of $100 \mathrm{mM}$ cinnamic acid and $0.1 \mu \mathrm{M}$ EBR in $1 / 2$ Hoagland's nutrient solution.

\subsection{Ultrastructure of Chloroplast and Thylakoid}

The ultrastructural difference of chloroplast and thylakoid between the C and C + EBR treatment was not obvious, chloroplast was fusiform, the outer membrane was clear, starch granule was clear and plump, and thylakoid grana lamellae were clear and folded regularly. Under autotoxicity stress conditions, chloroplast swelling, chloroplast outer membrane degradation, starch granulocyte blurring, and thylakoid granulocyte lamellae disappeared. Under CA + EBR treatment, the chloroplast presented fuzzy thylakoid granulocyte lamellae. Exogenous EBR markedly alleviated the damage caused by autotoxicity to chloroplast and thylakoid. Autotoxicity induced the degradation of the cell membrane; however, EBR application improved the cell membrane stability (Figure 4).

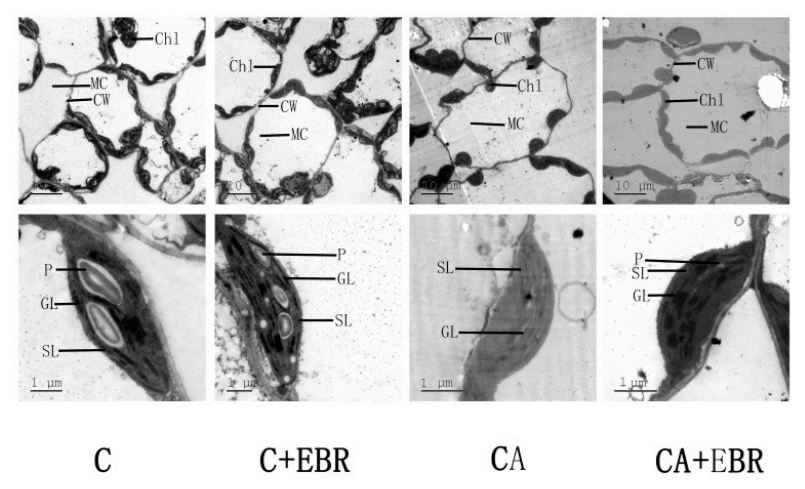

Figure 4. Chloroplast and thylakoid ultrastructure of cucumber leaves exposed to autotoxicity conditions with or without the application of EBR. MC, Mesophyll cell; Chl, chloroplast; CW, cell wall; GL, grana lamellae; SL, stroma lamellae; P, plastoglobules. C, 1/2 Hoagland's nutrient solution; C+EBR, application of $0.1 \mu \mathrm{M}$ EBR in 1/2 Hoagland's nutrient solution; CA, application of $100 \mathrm{mM}$ cinnamic acid in $1 / 2$ Hoagland's nutrient solution; CA+EBR, application of $100 \mathrm{mM}$ cinnamic acid and $0.1 \mu \mathrm{M}$ EBR in 1/2 Hoagland's nutrient solution.

\subsection{ROS, MDA and Relative Membrane Permeability}

Exogenous EBR application did not affect the ROS (i.e., $\mathrm{H}_{2} \mathrm{O}_{2}, \mathrm{O}_{2}{ }^{-},{ }^{\bullet} \mathrm{OH}$ ) and MDA contents of cucumber seedlings under normal growing conditions. CA treatment significantly increased ROS and MDA contents and relative electrical conductivity compared with control. However, EBR application markedly reduced ROS and MDA contents and relative electrical conductivity compared with CA 
treatment under autotoxicity stress conditions (Figure 5). Similar effects of EBR on leaf $\mathrm{H}_{2} \mathrm{O}_{2}$ accumulation, $\mathrm{O}_{2}{ }^{-}$production rate and lipid peroxidation were observed by an independent staining method (Figure 5B,D,F).
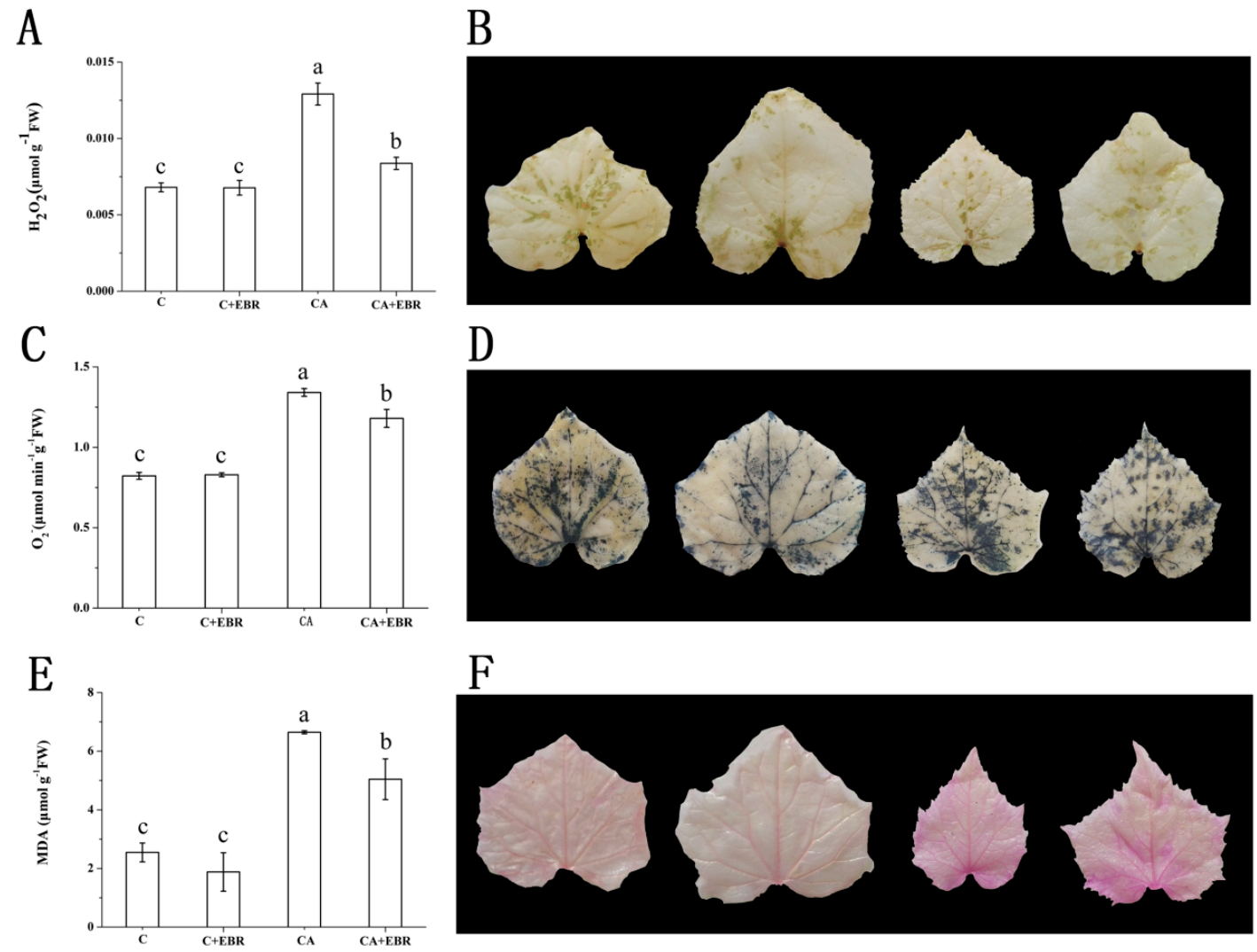

G

$\mathrm{C}$
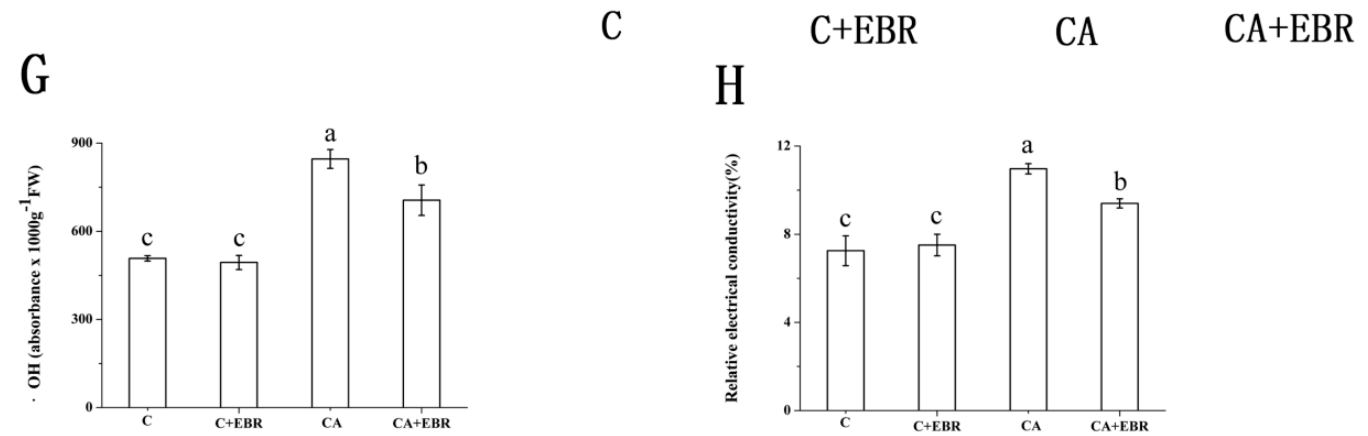

$\mathrm{H}$

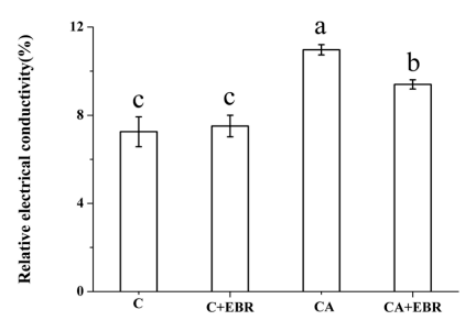

Figure 5. Change of ROS (A,C,G), lipid peroxidation (E) and relative conductivity (relative membrane permeability) $(\mathbf{H})$ in control condition, autotoxicity-stressed treatment, and autotoxicity-stress with EBR of cucumber seedlings. (A,C,E,G) are the quantitative measurements of $\mathrm{H}_{2} \mathrm{O}_{2}, \mathrm{O}_{2}{ }^{-}, \mathrm{MDA}$ and ${ }^{\bullet} \mathrm{OH}$ levels, respectively, in cucumber leaves under different treatments. Values are means of 6 replicates $\pm \mathrm{SE}$ $(n=6)$. Letters in the column diagram indicate significant differences at $p<0.05$. (B, $\mathbf{D}, \mathbf{F})$ are in situ detection of $\mathrm{H}_{2} \mathrm{O}_{2}, \mathrm{O}_{2}{ }^{-}$and lipid peroxidation in cucumber leaves via histochemical detection respectively. C, $1 / 2$ Hoagland's nutrient solution; $C+E B R$, application of $0.1 \mu \mathrm{M}$ EBR in 1/2 Hoagland's nutrient solution; $C A$, application of $100 \mathrm{mM}$ cinnamic acid in 1/2 Hoagland's nutrient solution; CA + EBR, application of $100 \mathrm{mM}$ cinnamic acid and $0.1 \mu \mathrm{M}$ EBR in 1/2 Hoagland's nutrient solution.

\subsection{Antioxidant System}

Under normal growing conditions, no significant differences were observed for POD, CAT and APX activity in cucumber seedlings by the application of EBR compared with control. However, EBR application improved the SOD, POD, APX and CAT activities by $4.40 \%, 11.10 \%, 17.50 \%$ and $35.80 \%$, 
respectively, in EBR-treated cucumber plants compared with CA-treated plants (Figure 6A,B,C,D). The contents of AsA and GSH in CA-treated cucumber seedlings were decreased by $26.40 \%$ and $30.10 \%$, respectively, compared with control. However, EBR application improved the AsA and GSH contents by $8.40 \%$ and $23.00 \%$, respectively compared with CA treatment under autotoxicity stress conditions (Figure 6E,F).

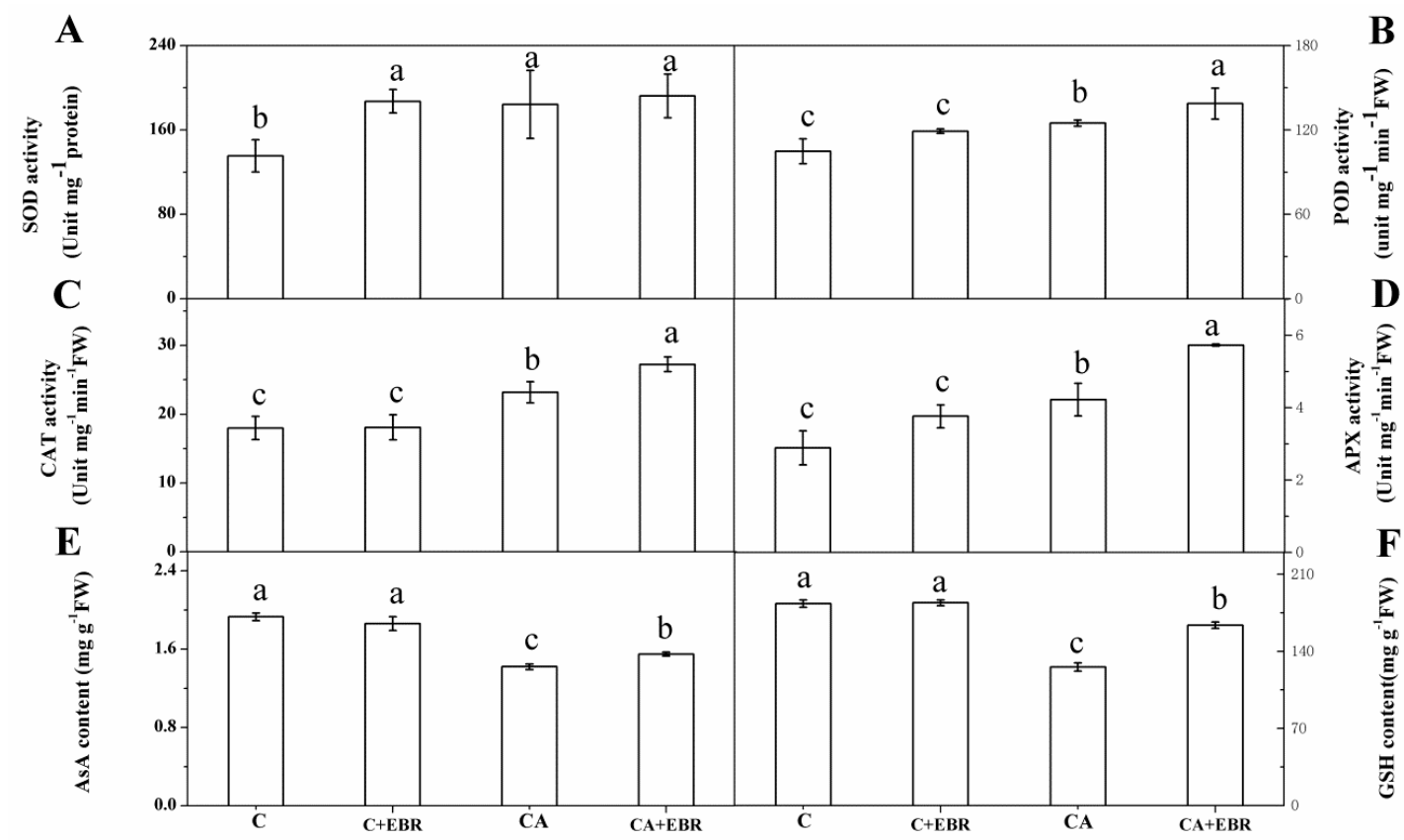

Figure 6. Changes of antioxidant system in leaves of cucumber seedlings under control or autotoxicity stress conditions with or without EBR. Letters in the column diagram indicate significant differences at $p<0.05$. (A-F) respectively is the activity of superoxide dismutase (SOD), peroxidase (POD), catalase (CAT), ascorbate peroxidase (APX) and antioxidative compounds ascorbate (AsA) and reduced glutathione (GSH) contents. C, 1/2 Hoagland's nutrient solution; $\mathrm{C}+\mathrm{EBR}$, application of $0.1 \mu \mathrm{M}$ EBR in 1/2 Hoagland's nutrient solution; CA, application of $100 \mathrm{mM}$ cinnamic acid in 1/2 Hoagland's nutrient solution; CA+EBR, application of $100 \mathrm{mM}$ cinnamic acid and $0.1 \mu \mathrm{M}$ EBR in 1/2 Hoagland's nutrient solution.

\subsection{Proline, Soluble Sugar and Protein Contents}

Under normal growing conditions, there was no significant difference in the proline, soluble sugar and protein contents among the EBR-treated and non-EBR treated cucumber plants. However, under autotoxicity stress conditions, EBR application markedly improved soluble protein, soluble sugar and proline contents (Table 6).

Table 6. The changes in proline, soluble sugar and protein contents of cucumber leaves under autotoxicity stress conditions.

\begin{tabular}{|c|c|c|c|}
\hline Treatment & $\begin{array}{c}\text { Soluble Protein } \\
\text { (mg g }{ }^{-1} \text { Fresh weight) }\end{array}$ & $\begin{array}{c}\text { Soluble Sugar } \\
\text { (mg g }{ }^{-1} \text { Fresh weight) }\end{array}$ & $\begin{array}{c}\text { Proline } \\
\left(\mu \mathrm{g} \mathrm{g}^{-1} \text { Fresh weight) }\right.\end{array}$ \\
\hline C & $15.90 \pm 0.48 c$ & $0.44 \pm 0.02 c$ & $19.66 \pm 3.16 c$ \\
\hline $\mathrm{C}+\mathrm{EBR}$ & $17.76 \pm 0.74 c$ & $0.46 \pm 0.02 c$ & $16.37 \pm 1.80 \mathrm{c}$ \\
\hline CA & $23.67 \pm 0.25 b$ & $0.67 \pm 0.08 b$ & $68.83 \pm 3.16 b$ \\
\hline $\mathrm{CA}+\mathrm{EBR}$ & $25.38 \pm 1.07 \mathrm{a}$ & $1.07 \pm 0.10 \mathrm{a}$ & $94.01 \pm 2.89 \mathrm{a}$ \\
\hline
\end{tabular}

Different lowercase letters in the same column indicate a significant difference between the treatments at $p<0.05$. Data are the mean \pm standard error of the mean of at least three different replicates of each treatment. C, $1 / 2$ Hoagland's nutrient solution; C + EBR, application of $0.1 \mu \mathrm{M}$ EBR in $1 / 2$ Hoagland's nutrient solution; CA, application of $100 \mathrm{mM}$ cinnamic acid in 1/2 Hoagland's nutrient solution; CA + EBR, application of $100 \mathrm{mM}$ cinnamic acid and $0.1 \mu \mathrm{M}$ EBR in $1 / 2$ Hoagland's nutrient solution. 


\section{Discussion}

BRs act as a positive regulator under stressful environmental conditions [19]. BRs are reported to alleviate temperature stress [41], drought stress, salinity stress [42], and heavy metals stress [43]. However, the role of BRs to alleviate autotoxicity stress for cucumber seedlings was not reported. In our study, we observed the effect of BRs on cucumber seedling under autotoxicity stress conditions. Root, as an important organ to absorb water and nutrients from the soil and transport them to aboveground plant parts, directly affects the morphogenesis and biomass accumulation of aboveground plant parts [44]. Under stress conditions, plant roots sense the stress signal, plants make adjustments in the metabolic pathways, change the carbon distribution ratio and direction of carbon assimilation products, and finally, root morphology is altered to adapt to the environmental stress [45]. Müssig et al. [46] reported that exogenous EBR application at $0.05-0.1 \mathrm{nM}$ stimulated the growth of the taproot of Arabidopsis thaliana, however, at higher concentration root growth inhibition was observed. In our study, exogenous application of EBR at $0.1 \mu \mathrm{M}$ improved the growth and biomass of root (Tables 2 and 3). $\mathrm{Li}$ et al. [47] showed that $0.1 \mu \mathrm{M}$ EBR treatment promoted the accumulation of rhoptry protein 2 (ROP2) in the root system from the central column to the elongation zone to respond to gravity and improved the polar distribution of ROP2 and actively regulated lateral root development. In the present study, exogenous application of $0.1 \mu \mathrm{M}$ EBR increased leaf area, plant height (Table 1) and aboveground biomass accumulation (Table 2), root activity (Figure 2), and root morphology (Table 3) as an important indicator of direct contact between roots and environmental conditions and reflected plant growth, suggesting that BRs can effectively promote the growth of cucumber seedlings under autotoxicity stress conditions. EBR increased root absorption area exposed to the nutrient medium, and enhanced the nutrients and water absorption ability to maintain their functional behavior.

In this study, we provided evidence that endogenous EBR played a positive role and improved photosynthetic pigments under autotoxicity stress in cucumber (Table 4). Chlorophyll is the main photosynthetic pigment which has the function of absorbing, transferring and converting light energy into chemical energy, and changes in photosynthetic pigments can be used as photosynthesis indicators [48]. Interestingly, application of exogenous EBR apparently increased the total chlorophyll, chlorophyll $\mathrm{a}$, and chlorophyll $\mathrm{b}$ contents of cucumber leaves under autotoxicity stress. The increased photosynthetic pigments are beneficial to capture more light energy and increase the rate of conversion of light energy to chemical energy [49]. We also observed increased stomatal opening by EBR application, indicating that BRs could help improve the availability of carbon for photosynthesis (Figure 3). Meanwhile, our evidence for gas exchange parameters showed the importance of BRs in regulating photosynthesis, an apparent increase in the net photosynthetic rate under autotoxicity stress conditions was observed (Table 5). We also found that autotoxicity caused damage to membrane system and organelles of cucumber leaves, and eventually, the chloroplasts were swollen, the outer membrane of chloroplast was degraded, the starch granules were fuzzy, thylakoids lamellae disappeared, and cell membrane degradation was increased (Figure 4). These damages reduced the photosynthetic efficiency of cucumbers and also caused damage to the antioxidant system. In this study, exogenous EBR apparently reduced the damage of chloroplast and thylakoids in cucumber leaves caused by autotoxicity, and maintained the relative stability of the organelle system (Figure 4).

It was reported that the level of ROS in the plants remains lower [50]. Plants could clean up excess reactive oxygen species through the antioxidant system and maintain the active oxygen homeostasis under normal circumstances. ROS are considered important for the growth and development of plants [51]. Under stress environment, plants produce ROS that causes normal active oxygen metabolism disorder in vivo [52]. In this study, we observed that EBR positively regulated $\mathrm{H}_{2} \mathrm{O}_{2}$, superoxide radical $\left(\mathrm{O}_{2}^{-}\right)$and the hydroxyl radical $\left({ }^{\bullet} \mathrm{OH}\right)$ under autotoxicity stress conditions (Figure 5). It proved that BRs could remove excessive ROS produced by autotoxicity stress in order to reduce ROS damage to the membranes. It was confirmed that antioxidant enzymes in plants work together and a single protective enzyme did not maintain the balance of active oxygen metabolism in cells [50]. Under stress conditions, because of changes in physiological and biochemical reactions, the activities 
of antioxidant enzymes, including POD, SOD, and CAT are reduced and excess reactive oxygen species, MDA, and other harmful substances generated in the plant are not removed in a timely fashion [53]. CAT was a major $\mathrm{H}_{2} \mathrm{O}_{2}$ scavenging enzyme, and SOD acted as an early defense against ROS, particularly $\mathrm{H}_{2} \mathrm{O}_{2}$ [22,54]. According to a report, EBR-mediated resistance could be attributed to the up-regulation of antioxidants-related genes ( $S O D, C A T, P O D, G R$, and APX) [22]. In our study, cucumber seedlings treated with EBR under autotoxicity conditions obviously enhanced the activities of antioxidant enzymes, such as SOD, CAT, POD, and APX (Figure 6). AsA and GSH are two important non-enzymatic antioxidants, they participate in the removal of free radicals and peroxidation products in plants, quench active oxygen, and protect enzymes and structural proteins to protect cell membrane of plants under stressful conditions [35]. Our findings showed that BR increased the AsA and GSH contents and helped cells to reduce ROS damage (Figure 6). The findings of MDA content and relative conductivity of cucumber leaves suggested that BRs have a positive effect and decrease cell membrane injury (Figure 6).

In order to further understand the mechanism of BRs alleviating the damage of cell membrane induced by autotoxicity, we measured the concentration of osmotic substances (soluble protein, soluble sugar and proline). In this study, we observed that EBR application enhanced the soluble protein, soluble sugar and proline contents in the cells indicating that EBR improved plant capacity to withstand autotoxicity stress. One of the major responses of autotoxicity on plant damage was the increased permeability of the cell membrane. In this experiment, autotoxicity stress significantly increased the membrane permeability of cucumber leaves. However, EBR treatment improved soluble protein, soluble sugar and proline contents of cucumber leaves, and improved membrane stability of cucumber (Table 6).

\section{Conclusions}

Autotoxicity affects normal metabolism of plants because of the accumulation of ROS and lipid peroxidation under autotoxicity stress conditions. ROS accumulation and lipid peroxidation leads to the destruction of cells structure and reduced plant growth. Under autotoxicity stress conditions, EBR application improves antioxidant contents (AsA and GSH) and the activities of antioxidant enzymes (POD, APX and CAT) and proline, soluble sugar, and soluble protein contents; resultantly $\bullet \mathrm{OH}, \mathrm{H}_{2} \mathrm{O}_{2}$ and $\mathrm{MDA}$ content are reduced, thus root damage is reduced and the integrity of chloroplast and thylakoid structure is maintained. Photosynthetic pigments and photosynthetic capacity of the cucumber leaves is improved. All these events lead to improved plant growth and development of cucumber seedlings under autotoxicity stress conditions. To further clarify the mechanism of EBR application to alleviate autotoxixity stress, gene expression analysis and genome wise transcriptome profiling can be considered. Based on the findings of this study, EBR application can help improve plant growth and development of cucumber under protected cultivation system.

Author Contributions: J.L. conceived and designed the experiments. P.Y., F.L. and L.B. performed the experiments and analyzed the data. M.A.N. helped perform the analysis with constructive discussions and writing this manuscript. All authors have read and approved the final manuscript.

Funding: The financial support for this study was provided by National Natural Science Foundation of China (31760592); Scientific Research Fund Project Yunnan Provincial Educational Department (2017ZZX119); Special Scientific Research Fund for PhD of Honghe University (XJ17B07; XJ17B08) and Yunnan Province Applied Basic Research Plan of China (2018FD087).

Acknowledgments: We are thankful to the staff of the Experimental Station of Honghe University for their assistance during this study.

Conflicts of Interest: The authors declare no conflict of interest.

\section{References}

1. Zhang, Y.; Gu, M.; Xia, X.; Shi, K.; Zhou, Y.; Yu, J. Alleviation of autotoxin-induced growth in hibition and respiration by sucrose in Cucumis sativus (L.). Allelopathy J. 2010, 25, 147-154. 
2. Paudel, M.N. Multiple Cropping for Raising Productivity and Farm Income of Small Farmers. J. Nepal Agric. Res. Counc. 2016, 2, 37-45. [CrossRef]

3. Chou, C. Roles of allelopathy in plant biodiversity and sustainable agriculture. Crit. Rev. Plant Sci. 1999, 18, 609-636. [CrossRef]

4. Bie, Z.; Nawaz, M.A.; Huang, Y.; Lee, J.M.; Colla, G. Introduction of vegetable grafting. In Vegetable Grafting, Principles and Practices; Colla, G., Alfocea, F.P., Schwarz, D., Eds.; CABI Publishing: Wallingford, UK, 2017; pp. 1-21.

5. Callaway, R.; Vivanco, J. Can plant biochemistry contribute to understanding of invasion ecology? Trends Plant Sci. 2006, 11, 574-580. [CrossRef]

6. Qiao, Y. Study on Different Responses to Autotoxin Toxicity in Cucumber and Figleaf Gourd Seedlings. Ph.D. Thesis, China Agricultural University, Beijing, China, 2013.

7. Li, J.; Li, Y.; Tian, Y.; Qu, M.; Zhang, W.; Gao, L. Melatonin has the potential to alleviate cinnamic acid stress in cucumber seedlings. Front. Plant Sci. 2017, 8, 1193. [CrossRef]

8. Seal, A.; Haig, T.; Pratley, J. Evaluation of putative allelochemicals in rice root exudates for their role in the suppression of arrowhead root growth. J. Chem. Ecol. 2004, 30, 1663-1678. [CrossRef]

9. Belz, R. Allelopathy in crop/weed interactions-an update. Pest Manag. Sci. 2007, 63, 308-326. [CrossRef]

10. FAO. FAOSTAT Domains/Production/Crops. Available online: http://www.fao.org/faostat/en/\#data/QC (accessed on 19 December 2016).

11. Xie, J.; Yu, J.; Chen, B.; Feng, Z.; Li, J.; Zhao, C.; Lyu, J.; Hu, L.; Gan, Y.; Kadambot, H. Facility cultivation systems “设施农业”: A Chinese model for the planet. Adv. Agron. 2017, 145, 1-42. [CrossRef]

12. Bennett, A.; Bending, G.; Chandler, D.; Hilton, S.; Mills, P. Meeting the demand for crop production: The challenge of yield decline in crops grown in short rotations. Biol. Rev. 2012, 87, 52-71. [CrossRef] [PubMed]

13. Al-Harbi, A.; Al-Omran, A.; Alharbi, K. Grafting improves cucumber water stress tolerance in Saudi Arabia. Saudi J. Biol. Sci. 2018, 25, 298-304. [CrossRef] [PubMed]

14. Nawaz, M.A.; Shireen, F.; Huang, Y.; Bie, Z.; Waqar, A.; Basharat, A. Perspectives of vegetable grafting in Pakistan, current status, challenges and opportunities. Int. Agric. Biol. 2017, 19, 1165-1174. [CrossRef]

15. Nawaz, M.A.; Muhamamd, I.; Kong, Q.; Cheng, F.; Waqar, A.; Huang, Y.; Bie, Z. Grafting: A technique to modify ion accumulation in horticultural crops. Front. Plant Sci. 2016, 7, 1457. [CrossRef] [PubMed]

16. Huang, Y.; Jiao, Y.; Nawaz, M.A.; Chen, C.; Liu, L.; Lu, Z.; Kong, Q.; Cheng, F.; Bie, Z. Improving magnesium uptake, photosynthesis and antioxidant enzyme activities of watermelon by grafting onto pumpkin rootstock under low magnesium. Plant Soil 2016, 409, 229-246. [CrossRef]

17. Alfocea, P.; Schwarz, D. (Eds.) Vegetable Grafting. Principles and Practices; CABI Publishing: Wallingford, UK, 2017; pp. 1-21.

18. Velkov, N.; Pevicharova, G. Effects of cucumber grafting on yield and fruit sensory characteristics. Zemdirbyste 2016, 103, 405-410. [CrossRef]

19. Vriet, C.; Russinova, E.; Reuzeau, C. Boosting crop yields with plant steroids. Plant Cell 2012, 24, 842-857. [CrossRef]

20. Krishna, P. Brassinosteroid-mediated stress responses. J. Plant Growth Regul. 2003, 22, 289-297. [CrossRef] [PubMed]

21. Bajguz, A.; Hayat, S. Effects of brassinosteroids on the plant responses to environmental stresses. Plant Physiol. Biochem. 2009, 47, 1-8. [CrossRef] [PubMed]

22. Cui, J.; Zhou, Y.; Ding, J.; Xia, X.; Shi, K.; Chen, S.; Asami, T.; Chen, Z.; Yu, J. Role of nitric oxide in hydrogenperoxide-dependent induction of abiotic stress tolerance by brassinosteroids in cucumber. Plant Cell Environ. 2011, 34, 347-358. [CrossRef]

23. Xia, X.; Fang, P.; Guo, X.; Qian, X.; Zhou, J.; Shi, K.; Zhou, Y.; Yu, J. Brassinosteroid-mediated apoplastic $\mathrm{H}_{2} \mathrm{O}_{2}$-glutaredoxin 12/14 cascade regulates antioxidant capacity in response to chilling in tomato. Plant Cell Environ. 2018, 41, 1052-1064. [CrossRef]

24. Hu, W.; Wu, Y.; Zeng, J.; He, L.; Zeng, Q. Chill-induced inhibition of photosynthesis was alleviated by 24-epibrassinolide pretreatment in cucumber during chilling and subsequent recovery. Photosynthetica 2010, 48, 537-544. [CrossRef] 
25. Eremina, M.; Unterholzner, S.; Rathnayake, A.; Castellanos, M.; Khan, M.; Kugler, K.; Poppenberger, B. Brassinosteroids participate in the control of basal and acquired freezing tolerance of plants. Proc. Natl. Acad. Sci. USA 2016, 113, E5982-E5991. [CrossRef] [PubMed]

26. Jiang, Y.; Huang, L.; Cheng, F.; Zhou, Y.; Xia, X.; Mao, W.; Shi, K.; Yu, J. Brassinosteroids accelerate recovery of photosynthetic apparatus from cold stress by balancing the electron partitioning, carboxylation and redox homeostasis in cucumber. Physiol. Plant. 2013, 148, 133-145. [CrossRef] [PubMed]

27. Todorova, D.; Talaat, N.B.; Katerova, Z.; Alexieva, V.; Shawky, B. Polyamines and brassinosteroids in drought stress responses and tolerance in plants. In Water Stress and Crop Plants, 1st ed.; Ahmad, P., Ed.; John Wiley \& Sons, Ltd.: Hoboken, NY, USA, 2016; pp. 608-627.

28. Liu, Z.; Li, L.; Luo, Z.; Zeng, F.; Jiang, L.; Tang, K. Effect of brassinolide on energy status and proline metabolism in postharvest bamboo shoot during chilling stress. Postharvest Biol. Technol. 2016, 111, 240-246. [CrossRef]

29. Kang, Y.; Guo, S.; Li, J.; Duan, J. Effect of root applied 24-epibrassinolide on carbohydrate status and fermentative enzyme activities in cucumber (Cucumis sativus L.) seedlings under hypoxia. Plant Growth Regul. 2008, 57, 259-269. [CrossRef]

30. Bu, R.; Wang, R.; Wei, Q.; Hu, H.; Sun, H.; Song, P.; Yu, Y.; Liu, Q.; Zheng, Z.; Li, T.; et al. Silencing of glycerol-3-phosphate acyltransferase 6 (GPAT6) gene using a newly established virus induced gene silencing (VIGS) system in cucumber alleviates autotoxicity mimicked by cinnamic acid (CA). Plant Soil. 2019, 438, 329-346. [CrossRef]

31. Li, J.; Yang, P.; Xie, J.; Yu, J. Effects of 24-epibrassinolide on growth and antioxidant enzymes system in pepper roots under chilling stress. J. Nucl. Agric. Sci. 2015, 29, 1001-1008. [CrossRef]

32. Arnon, D. Copper enzymes in isolated chloroplasts polyphenoloxidase in beta vulgaris. Plant Physiol. 1949, 24, 1-15. [CrossRef] [PubMed]

33. Zeng, Y.; Zhang, Y.; Xiang, J.; Wu, H.; Chen, H.; Zhang, Y.; Zhu, D. Effects of chilling tolerance induced by spermidine pretreatment on antioxidative activity, endogenous hormones and ultrastructure of indica-japonica hybrid rice seedlings. J. Integr. Agric. 2016, 15, 295-308. [CrossRef]

34. Ma, N.; Zuo, Q.; Liang, X.; Yin, B.; Wang, Q.; Meng, D. The multiple stress-responsive transcription factor SINAC1 improves the chilling tolerance of tomato. Physiol. Plant. 2013, 149, 474-486. [CrossRef]

35. Li, J.; Yang, P.; Gan, Y.; Yu, J.; Xie, J. Brassinosteroid alleviates chilling-induced oxidative stress in pepper by enhancing antioxidation systems and maintenance of photosystem II. Acta Physiol. Plant. 2015, 37, 222. [CrossRef]

36. Stevens, R.; Page, D.; Gouble, B.; Garchery, C.; Zamir, D.; Causse, M. Tomato fruit ascorbic acid content is linked with monodehydroascorbate reductase activity and tolerance to chilling stress. Plant Cell Environ. 2008, 31, 1086-1096. [CrossRef]

37. Griffith, O.W. Determination of glutathione and glutathione disulphide using glutathione reductase and 2-vinylpyridine. Anal. Biochem. 1980, 106, 207-212. [CrossRef]

38. Bates, L.S.; Waldren, R.P.; Teare, I.D. Rapid determination of free proline for water-stress studies. Plant Soil 1973, 39, 205-207. [CrossRef]

39. Buysse, J.; Merckx, R. An improved colorimetric method to quantify sugar content of plant tissue. J. Exp. Bot. 1993, 44, 1627-1629. [CrossRef]

40. Bradford, M. A rapid and sensitive method for the quantitation of microgram quantities of protein utilizing the principle of protein dye binding. Anal. Biochem. 1976, 72, 248-254. [CrossRef]

41. Sadura, I.; Janeczko, A. Physiological and molecular mechanisms of brassinosteroid-induced tolerance to high and low temperature in plants. Biol. Plant. 2018, 62, 601-616. [CrossRef]

42. Shahbaz, M.; Ashraf, M.; Athar, H. Does exogenous application of 24-epibrassinolide ameliorate salt induced growth inhibition in wheat (Triticum aestivum L.)? Plant Growth Regul. 2008, 55, 51-64. [CrossRef]

43. Sharma, I.; Pati, P.; Bhardwaj, R. Effect of 24-epibrassinolide on oxidative stress markers induced by nickel-ion in Raphanus satious L. Acta Physiol. Plant. 2011, 33, 1723-1735. [CrossRef]

44. Cheng, J.; Dai, T.; Jing, Q.; Jiang, D.; Pan, X.; Cao, W. Root morphological and physiological characteristics in relation to nitrogen absorption efficiency in different rice genotypes. Acta Pedol. Sin. 2007, 44, $266-272$. [CrossRef]

45. Pierret, A.; Doussan, C.; Capowiez, Y.; Bastardie, F.; Pagès, L. Root functional architecture: A framework for modeling the interplay between roots and soil. Vadose Zone J. 2007, 6, 269-281. [CrossRef] 
46. Müssig, C.; Shin, G.; Altmann, T. Brassinosteroids promote root growth in Arabidopsis. Plant Physiol. 2003, 133, 1261-1271. [CrossRef]

47. Li, L.; Xu, J.; Xu, Z.; Xue, H. Brassinoeroids stimulate plant tropisms through modulation of polar auxin transport in Brassica and Arabidopsis. Plant Cell 2005, 17, 2738-2753. [CrossRef] [PubMed]

48. Ahammed, G.; Yuan, L.; Ogweno, J.; Zhou, Y.; Xia, X.; Mao, W.; Shi, K.; Yu, J. Brassinosteroid alleviates phenanthrene and pyrene phytotoxicity by increasing detoxification activity and photosynthesis in tomato. Chemosphere 2012, 86, 546-555. [CrossRef] [PubMed]

49. Jiang, L.; Wen, L. 2-Photonic sensitive switchable materials A2-Meglinski, Igor. In Biophotonics for Medical Applications; Woodhead Publishing: Cambridge, UK, 2015; pp. 25-51.

50. Xia, X.; Wang, Y.; Zhou, Y.; Tao, Y.; Mao, W.; Shi, K.; Asami, T.; Chen, Z.; Yu, J. Reactive oxygen species are involved in brassinosteroid-induced stress tolerance in cucumber. Plant Physiol. 2009, 150, 801-814. [CrossRef]

51. Xia, X.; Huang, L.; Zhou, Y.; Mao, W.; Shi, K.; Wu, J.; Asami, T.; Chen, Z.; Yu, J. Brassinosteroids promote photosynthesis and growth by enhancing activation of Rubisco and expression of photosynthetic genes in Cucumis sativus. Planta 2009, 230, 1185-1196. [CrossRef]

52. Cao, S.; Xu, Q.; Cao, Y.; Qian, K.; An, K.; Zhu, Y.; Hu, B.; Zhao, H.; Kuai, B. Loss of function mutations in DET2 gene lead to an enhanced resistance to oxidative stress in Arabidopsis. Physiol. Plant. 2005, 123, 57-66. [CrossRef]

53. Muhammad, A.; Chen, C.; Fareeha, S.; Zheng, Z.; Jiao, Y.; Hamza, S.; Muhammad, A.; Muhammad, I.; Muhammad, A.; Huang, Y.; et al. Improving vanadium stress tolerance of watermelon by grafting onto bottle gourd and pumpkin rootstock. Plant Growth Regul. 2018, 85, 41-56. [CrossRef]

54. Wang, P.; Sun, X.; Li, C.; Wei, Z.; Liang, D.; Ma, F. Long-term exogenous application of melatonin delays drought-induced leaf senescence in apple. J. Pineal Res. 2013, 54, 292-302. [CrossRef]

(C) 2019 by the authors. Licensee MDPI, Basel, Switzerland. This article is an open access article distributed under the terms and conditions of the Creative Commons Attribution (CC BY) license (http://creativecommons.org/licenses/by/4.0/). 